\title{
GREEN BEHAVIOR AND THE USE OF ECO-PRODUCT: MILLENNIAL GENERATION PERSPECTIVE
}

\section{Antonius Alijoyo, Imam Sapuan}

Parahyangan Catholic University, Bandung ${ }^{1}$, Pasundan University ${ }^{2}$, Indonesia Email: antonius.alijoyo@gmail.com, imam.sapuan@unpas.ac.id

\begin{tabular}{|c|c|}
\hline ARTICLE INFO & ABSTRACT \\
\hline $\begin{array}{l}\text { Received: } \\
\text { December, 26th } \\
2021 \\
\text { Revised: } \\
\text { January, 17th } \\
2022 \\
\text { Approved: } \\
\text { January, 18th } \\
2022\end{array}$ & $\begin{array}{l}\text { Global warming is a problem that has not been overcome } \\
\text { until now and even tends to get worse. This study was } \\
\text { conducted to identify the awareness of the millennial } \\
\text { generation as the next generation towards green behavior } \\
\text { and the use of eco-products. This study was conducted by } \\
\text { following a systematic literature review approach. Research } \\
\text { data is collected from scientific journal articles indexed by } \\
\text { Scopus and Sinta regarding green behavior and eco- } \\
\text { products published in 2016-2021. The data is also focused } \\
\text { on studies that make the millennial generation the subject } \\
\text { of research. The data collected was then analyzed } \\
\text { descriptively qualitatively. This study found that the } \\
\text { millennial generation understands and is concerned for the } \\
\text { environment and has begun to implement green behavior. } \\
\text { This understanding arises because of the availability of } \\
\text { various information both in the printed and electronic form } \\
\text { regarding the negative impacts of global warming and } \\
\text { climate change. Millennials' concern for the environment is } \\
\text { shaped by their understanding and regulations to } \\
\text { implement green behavior to create a green environment. } \\
\text { However, based on data from various sources, the results } \\
\text { achieved so far have not shown significant changes to } \\
\text { overcome the problems of global warming and climate } \\
\text { change which tend to worsen. }\end{array}$ \\
\hline KEY & $\begin{array}{l}\text { Eco-Product, Global Warming, Green Behavior, } \\
\text { Millennial Generation }\end{array}$ \\
\hline
\end{tabular}

How to cite: 


\section{INTRODUCTION}

Global warming is a global problem that until now still cannot be solved. Global warming is the average temperature of the earth's atmosphere, oceans, and land (Ninawe et al., 2018). This happens because of the trapping of the sun's long waves (heat waves or infrared) emitted to the earth by greenhouse gases (Sullivan, 2008). Greenhouse gases are naturally present in the air (atmosphere). Global warming is a global phenomenon triggered by human activities, especially those related to fossil materials and land use conversion activities (V. Kumar et al., 2021). These activities produce more and more gases in the atmosphere, especially carbon dioxide (CO2), through a process that has a greenhouse effect (M. Biron, 2016; Park \& Seo, 2011). Called the greenhouse effect because of an increase in the earth's temperature due to heat trapped in the earth's atmosphere. The process is similar to a greenhouse that works to keep the plants warm inside. The increase in temperature in the greenhouse occurs because the sun's rays are too close to the objects in the greenhouse that are blocked by the glass walls, so that air cannot get out (Muralikrishna \& Manickam, 2017).

The increasing temperature of the earth causes various adverse impacts on the environment and other ecosystems because it triggers global climate change (Muralikrishna \& Manickam, 2017). One example of the impact of global warming is the melting of glaciers and polar ice caps. This can lead to rising sea levels and make some areas submerged in seawater (Diaz, 2019; Zikra et al., 2015). Examples of other adverse effects of global warming are high rainfall, crop failure, coral reefs, various types of species, to the depletion of the ozone layer in the earth's atmosphere (Feng et al., 2021; Pirovani et al., 2018; Tanure et al., 2020).

The occurrence of climate change, or the phenomenon of climate deviation, can also cause various hydrometeorological disasters, namely hurricanes, floods, and landslides, high sea waves (Mori et al., 2021). This happens because of climate instability, such as heat energy and a lot of water vapor in the atmosphere, much higher rainfall, bigger hurricanes, shifts in the rainy and dry seasons, unpredictable and extreme weather changes (Bellprat et al., 2015; Christidis \& Stott, 2021; Loo et al., 2015). If such a disaster occurs, it will cause material losses and even fatalities. In addition, global warming also disrupts yields due to extreme weather conditions, so that the dry season in tropical countries can cause severe droughts. Furthermore, global warming causes very extreme weather and health problems, especially infectious diseases (Kurane, 2010; Liang \& Gong, 2017; Waits et al., 2018; X. Wu et al., 2016).

Due to the many negative impacts caused by global warming, to overcome global problems, it is necessary to raise awareness of all human beings. This awareness must then be realized in real activities. In other words, this understanding must be seen from the behavior of everyone who wants to protect and maintain the environment, which is done because of the awareness and responsibility for the preservation of the universe. Such behavior is known as green behavior (Xiao et al., 2021). One concrete example of green behavior that all people can apply in reducing global warming is by using ecoproducts. Considering the importance of global warming and the role of green behavior in overcoming global warming, this research aims to find green behavior and the use of ecoproducts by millennials. Specifically, this study seeks to find out how the millennial generation understands green behavior and what the millennial generation has used ecoproducts as an effort to suppress global warming. 


\section{RESEARCH METHOD}

This research was conducted by following the Systematic Literature Review (SLR) approach. This research has four stages: designing the review, conducting the review, analysis, and writing the review (2019). The study data were collected from the articles from international journals indexed by Scopus and Sinta indexed national journals. Search articles are carried out through Scopus indexed article provider portals such as ScienceDirect, Hindi, NCBI, and MDPI. Furthermore, the journal that published the article was checked again on Scimago and Scopus to ensure that the journal that published the article was listed on Scopus and had a clear Q rating. Likewise, national journals are also checked on the Sinta website to ensure that the national journal is indexed by Sinta. The selected articles are published from 2016 to 2021 which discuss green behavior and eco-friendly products by the millennial generation. The collected data was then analyzed qualitatively with an interactive model analysis technique consisting of three stages, data reduction, data display, and conclusion drawing/verification (Miles et al., 2014).

\section{RESULT AND DISCUSSION}

\section{A. Millennial Generation}

The millennial generation is the generation born in the early 1980s to 2000 (Lupien \& Oldham, 2012). This generation is often called Gen-Y, Net Generation, Generation WE, Boomerang Generation, and Peter Pan Generation. They are called the millennial generation because they are the generation that lives at the turn of the millennium (Tait, 2019). Simultaneously in this era, digital technology began to penetrate into all aspects of life. Generation $\mathrm{Y}$ is known as the millennial generation or millennium. This generation uses a lot of instant communication technology such as email, SMS, instant messaging, and social media such as Facebook and Twitter, IG, and others, so in other words, Generation $\mathrm{Y}$ is the generation that grew up in the booming internet era (C. M. Barnum, 2021). Based on this definition, it can be concluded that the millennial generation is the generation born between 1980-2000 when there was rapid technological progress. The characteristics of the millennial generation are: 1) millennials trust usergenerated content (UGC) more than unidirectional information, 2) millennials prefer cellphones over TV, 3) millennials must-have social media, 4) millennials do not like to read conventionally, 5) millennials tend to be disloyal but work effectively 6) millennials tend to make cashless transactions, 7) millennials know more about technology than their parents, 8) millennials use technology and information, 9) millennials tend to be more lazy and consumptive (Au-Yong-Oliveira et al., 2018; Kurz et al., 2019).

\section{B. Green Behavior}

Green behavior is the behavior of protecting and maintaining the environment that is carried out because of the awareness and sense of responsibility for preserving the environment (Unsworth et al., 2021). Green behavior must manifest into actions based on values, norms, and compassion for the environment (Welsch et al., 2021). Thus, green behavior patterns can be seen from the daily behavior of individuals, such as maintaining the cleanliness of the home environment, throwing garbage in its place, consuming healthy food, recycling household waste, using electricity and water as needed. In other words, green behavior is human ethics in treating their environment. 
The focus of green behavior is human moral rules in animating love behavior towards the environment. Green behavior reflects responsibility and concern for the environment that must exist and be owned by every human being. The formation of human behavior towards the environment is related to attitudes and values that come from knowledge, feelings, and tendencies to act (Zhang \& Chabay, 2020). From this, human actions towards the environment are carried out based on decisions that come from environmental information and background experiences and attitudes towards the environment.

The interesting thing about green behavior in human relations with the surrounding environment is place identity and environmental awareness. Place identity is a substructure of a person's self-identity, which contains knowledge about the physical environment in which he lives. This is related to a meaningful place and emotionally has meaning in life for him. Green behavior is expected to become a lifestyle that all individuals own in the 21 st century. Green behavior as a lifestyle will create a balance in the ecosystem so that nature and the living things in it can live in prosperity (Iddagoda et al., 2021). Of course, this is not something that can be created without real effort.

Green behavior is influenced by seven variables ( $\mathrm{Bu} \& \mathrm{Go}$, 2008; Joshi \& Rahman, 2015), namely: (1) Environment attitude (attitude towards the environment), which refers to the individual's cognitive assessment of the value of environmental protection; (2) Environmental concern, namely the level of emotional involvement in environmental issues; (3) Perceived seriousness of environmental problems; (4) Perceived environmental responsibility; (5) Perceived effectiveness of environmental behavior; (6) Perceived self-image in environmental protection; and (7) Peer-influence. Environmental awareness is a multidimensional construction consisting of cognitive, attitude, and behavioral components (Omoogun et al., 2016; Paradewari et al., 2018). Consumers with a high level of environmental awareness make purchasing decisions for environmentally friendly products compared to products that pay less attention to environmental issues (Malik \& Singhal, 2017). Thus, environmental awareness measures will be more closely related to purchasing habits than sociodemographic or personality variables (Alamsyah et al., 2020). To see the level of consumer awareness of environmental sustainability, their buying behavior towards environmentally friendly products can explain it.

\section{Eco-product}

Awareness of the importance of protecting the environment will later lead individuals to green consumers' behavior, individual behavior that is influenced by their concern for the environment (Taufique \& Vaithianathan, 2018). The individual reflects this behavior when he searches for, buys, uses, evaluates, and disposes of products (Zhao et al., 2014). The behavior of consumers who care about the environment will affect their desire to consume environmentally friendly products (Dhir et al., 2021; Mobrezi \& Khoshtinat, 2016; Zaidi et al., 2021). Various environmental issues began to become a concern for the world community in the 90s era. Environmentally friendly products or green products are products that in the production process use production technology that does not pollute the environment and uses raw materials and packaging made from recyclable materials (A. Kumar et al., 2021). Thus, green products result from a production process that is safe for the environment and has a safe usage impact on the environment.

Green products describe products that protect or enhance the natural environment, conserve energy, and reduce or eliminate toxic agents, pollution, and waste (Lü et al., 2015; Tian \& Bilal, 2020). Rahnama \& Rajabpour (2017) categorize green products into four types. The first type is the product does not contain harmful elements when 
consumed, and the product can help preserve the environment without producing pollution. The second type is efficiency in energy use, where green products are more efficient than other conventional products. The third type is products made from raw materials that provide recycling functionality, and the fourth type is a product with a production process technology that is environmentally friendly.

Those who always use environmentally friendly products can be called environmentally friendly consumers. They adopt environmentally friendly behavior and/or purchase environmentally friendly products over standard alternatives (Shamdasani, Chon-Lin, \& Richmond, 1993). A person who purchases a product is influenced by his own awareness of environmental problems (Shrum, McCarty, \& Lowrey, 2013). Environmentally friendly consumers tend to consume environmentally friendly products (Herri \& Putri, 2006).

Consumer awareness will arise and become stronger if they are provided with complete and accurate information and knowledge about environmental issues (Ramayah et al., 2010). Good consumer knowledge will encourage positive behavior towards environmental sustainability. The higher the public knowledge about the environment, the more awareness to buy environmentally friendly products (Okada et al., 2019). Therefore, producers need to implement strategies, including creating and using environmentally friendly components, including eco-labeling to standardize products, certification, and communicating that the products they offer are included in the classification of environmentally friendly products. More specifically, Luzio and Lemke (2013) state that there are relevant factors that help to understand this green consumer behavior, including:

a. Reasons to buy green products

It is a reason to buy green products. Green consumers consume products for reasons made from natural ingredients and include concern about environmental issues.

b. Pricing

Price and cost savings are closely related to the consumption process. For example, when an item is included in the luxury category, such as a car, consumers will place the environment as a factor that is not too important because they have paid a lot, but when an item is included in the cheap category, consumers are more willing to pay for environmental reasons.

c. Perceived product confidence

Belief in green products that information about perceived benefits is true and is not merely greenwashing or just business practices.

d. Willingness to compromise

A consumer's willingness to pay a premium price and accept a product with a lower level of performance or appearance for the environment's sake.

e. Product characteristics

The character of green products influences consumer decisions and makes consumers determine alternatives in choosing products.

f. Knowledge

Knowledge of the environment affects the behavior of green consumers. For example, green consumers may use their environmental knowledge to refrain from purchasing green products because they know that they do not match the advertisement.

g. Considerations of alternatives

Consumers consider alternatives regarding green and non-green products, where companies deliberately use the name green products to sell even though the product is not green.

h. Product's point of purchase 
The point of purchasing products where consumers search for and buy green products in places that they feel comfortable and have added value, more precisely, is the selection of alternatives for where to buy green products.

i. Use and disposal

Product use and product disposal where green consumers know how to use green products, with what technology green products are made, and how product design can attract consumers. Thus, these green products can meet the needs in use and disposal for green consumers.

\section{Millennial Generation and Green Behavior}

The data collected found that the millennial generation has a good understanding and concern for environmental sustainability (Jiménez Correa et al., 2021; Luger et al., 2021; Sogari et al., 2017). This is evidenced by the many environmental conservation activities initiated by millennials. The examples are:

a. Reducing the use of Plastic Bags

Since the millennial generation has a good understanding and knowledge of the importance of environmental sustainability, they are actively involved in reducing the use of plastic bags for shopping (Dilotsotlhe, 2021; Lakatos et al., 2018). For example, the millennial generation's understanding of the dangers of plastic waste in Indonesia has been proven to make the millennial generation in Indonesia reduce the use of plastic bags (Ministry of National Planning and Development Indonesia, 2021). This habit is also supported by policies issued by the government, such as the prohibition of the use of plastic bags in modern shops that are applied in Bali, Indonesia (Antari \& Pangaribuan, 2021). In addition, the millennial generation also shows their awareness of the plastic waste that polluted the sea and ocean (Hansen et al., 2013; Kusumawati et al., 2020).

b. Recycle plastic waste

Many millennials also do plastic waste recycling. It was done by creating a waste bank, which accommodates and buys plastic waste brought by the community for recycling (Hansen et al., 2013; (Garcia et al., 2019). In addition, with current technological developments, some youths have also developed vending machines specifically for waste that can exchange plastic waste that is thrown into the vending machine into digital money (Sinclair, Sagar, Knudsen, Sabu, \& Ghermandi, 2021); (Sambhi \& Dahiya, 2020). Furthermore, several youths have also succeeded in converting plastic waste into premium fuel oil and diesel ( $\mathrm{Li}$ et al., 2022) (Bianchi \& da Silva Nogueira, 2019) (Ade et al., 2020)).

c. Reuse of plastic waste

Creative millennials have succeeded in utilizing plastic waste as the basic material for making handicrafts (Aminudin \& Nurwati, 2019) (Lokajaya \& Indo, 2019). There are various types of handicrafts that have been made by millennials using basic materials in the form of plastic waste. The handicrafts in the form of plastic bottle waste can be used as candle holders, photo frames, stationery holders, tissue holders, piggy banks, decorative lights, decorative flowers, bag decorations, refrigerator decorations, earrings, bracelets, necklaces, key chains, cellphone hangers, headbands, and brooch (Hasibuan, Damanik, \& Nasution, 2019). Not only as handicrafts but plastic waste has also been successfully converted into various fashion products. For example, the use of 
plastic waste into tote bags and wallets with the concept of sustainable fashion (Bestari, 2020).

\section{E. Millennial Generation and Eco-Product}

Ecological knowledge and ecological concern have an influence on buying interest in green products (Sutikno \& Anandya, 2021). In addition, factors that also positively influence the selection of green products are demographic characteristics such as gender, age, education level, occupation, and respondents' expenditures (Lestari \& Kardinal, 2018). Several studies show that the millennial generation has good Ecological knowledge. They understand the importance of preserving nature and the dangers of environmental pollution. They also know that global warming has occurred and has made climate change that has many negative effects on human life or other living things.

Based on this understanding, many millennials have chosen to buy eco-products (Atmando, 2019). For this reason, eco-product labels for environmentally friendly products are important to attract the attention of the millennial generation (Awual, Hasan, Rahman, \& Asiri, 2019). Because those who understand and are concerned for the environment will prefer products that have been proven to be environmentally friendly, by being labeled eco-product, those interested in buying environmentally friendly products can more easily choose the products they need. In addition, in general, the millennial generation also considers the price, quality, and packaging of the available eco-products. More quality, attractive, and affordable in terms of price will make ecoproducts more attractive to millennials. This means that the development of eco-products needs to consider these aspects to become products of interest and can later have a positive impact on environmental conservation. Eco-products that millennials demand include eco-friendly bags, electric cars, and eco-friendly homes (Gunawan \& Ferdhian, 2020); (Damayanti et al., 2021), (Harahap, Parinduri, \& Fitria, 2018)

\section{CONCLUSION}

Global warming and climate change are a threat to all living things on earth. It takes awareness of all human beings to overcome these problems. From the results of this study, it can be concluded that the millennial generation has a good understanding of the importance of environmental conservation and the negative impact of global warming. Therefore, the millennial generation has been proven to make various efforts to save the environment. With this understanding, many of them have taken advantage of ecoproducts that can help suppress the increase in global warming. However, these efforts must continue to be carried out and disseminated to realize the resulting positive impacts more quickly. Seeing that this research was only conducted using the SLR method and the data were analyzed qualitatively, further research is needed that can describe the understanding of the millennial generation regarding the importance of eco-products and green behavior along with the factors that can support the realization of green behavior for all generations. For this reason, a wider study using a mixed-method approach needs to be carried out to provide more detailed results so that they can be utilized in the formulation of practical steps that can be applied for comprehensive environmental conservation. 


\section{REFERENCES}

Ade, P., Aravena, M., Barria, E., Beelen, A., Benoit, Angélique, Béthermin, M., Bounmy, J., Bourrion, O., Bres, G., \& De Breuck, C. (2020). A wide fieldof-view low-resolution spectrometer at APEX: Instrument design and scientific forecast. Astronomy \& Astrophysics, 642, A60.

Aminudin, A., \& Nurwati, N. (2019). Pemanfaatan sampah plastik menjadi kerajinan tangan guna meningkatkan kreatifitas warga sekitar Institut Teknologi dan Bisnis Ahmad Dahlan (ITB-AD) Jakarta. Jurnal Abdimas BSI Jurnal Pengabdian Kepada Masyarakat, 2(1), 66-79.

Atmando, Citra Ridho. (2019). Pengaruh Persepsi Green Product dan Green Brand Image Terhadap Minat Beli Rumah Ramah Lingkungan Pada Generasi Y di Surabaya. PERFORMA: Jurnal Manajemen Dan Start-Up Bisnis, 4(3), 394-405.

Awual, Md Rabiul, Hasan, Md Munjur, Rahman, Mohammed M., \& Asiri, Abdullah M. (2019). Novel composite material for selective copper (II) detection and removal from aqueous media. Journal of Molecular Liquids, 283, 772-780.

Bianchi, Renzo, \& da Silva Nogueira, Daniel. (2019). Burnout is associated with a depressive interpretation style. Stress and Health, 35(5), 642-649.

Damayanti, Diana, Rimadias, Santi, Haque, Marissa Grace, Sunarsi, Denok, Kosasih, Kosasih, \& Kesumadewi, Raden Roro Vemmi. (2021). Peran Work Overload, Work Environment, Work Family Conflict \& Work Stress Terhadap Job Performance. Jurnal Ilmiah Wahana Pendidikan, 7(3), 192206.

Garcia, Pablo, Aspee, Karla, Ramirez, Georges, Dettleff, Phillip, Palomino, Jaime, Peralta, Oscar A., Parraguez, Víctor H., \& De los Reyes, Monica. (2019). Influence of growth differentiation factor 9 and bone morphogenetic protein 15 on in vitro maturation of canine oocytes. Reproduction in Domestic Animals, 54(2), 373-380.

Gunawan, Theresia, \& Ferdhian, Michael Alexander. (2020). GREEN STRATEGY PERUSAHAAN PLASTIK DALAM MENGHADAPI TANTANGAN LINGKUNGAN DAN PEMERINTAH. Jurnal Administrasi Bisnis, 16(1), 57-69.

Harahap, Bonar, Parinduri, Luthfi, \& Fitria, An Ama Lailan. (2018). Analisis Pengendalian Kualitas Dengan Menggunakan Metode Six Sigma (Studi Kasus: PT. Growth Sumatra Industry). Buletin Utama Teknik, 13(3), 211218.

Hasibuan, Siti Rohaniah, Damanik, Marini, \& Nasution, Hafni Indriati. (2019).

Differences in Learning Models of Problem Based Learning and NHT

Cooperative Type with Card Media Assistance to Student Learning Outcomes and Activities in Naming Chemical Compounds. Journal of Transformative Education and Educational Leadership, 1(1), 18-22.

Lestari, Retno Budi, \& Kardinal, Kardinal. (2018). Minat Beli Produk Hijau pada Generasi Milenial. Jurnal Ilmiah Ekonomi Global Masa Kini, 9(2), 117-124. 
Li, Shijie, Wang, Chunchun, Cai, Mingjie, Yang, Fang, Liu, Yanping, Chen, Jialin, Zhang, Peng, Li, Xin, \& Chen, Xiaobo. (2022). Facile fabrication of TaON/Bi2MoO6 core-shell S-scheme heterojunction nanofibers for boosting visible-light catalytic levofloxacin degradation and $\mathrm{Cr}$ (VI) reduction. Chemical Engineering Journal, 428, 131158.

Lokajaya, I. Nyoman, \& Indo, Whilyan. (2019). PENGOLAHAN LIMBAH PLASTIK MENJADI PRODUK KERAJINAN TANGAN UNTUK MENINGKATKAN EKONOMI MASYARAKAT SENDANG DAJAH. Jurnal Abdikarya: Jurnal Karya Pengabdian Dosen Dan Mahasiswa, 3(4).

Sambhi, Shilpa, \& Dahiya, Preeti. (2020). Reverse vending machine for managing plastic waste. International Journal of System Assurance Engineering and Management, 11(3), 635-640.

Sinclair, Michael, Sagar, M. K. Vishnu, Knudsen, Camilla, Sabu, Joseph, \& Ghermandi, Andrea. (2021). Economic appraisal of ecosystem services and restoration scenarios in a tropical coastal Ramsar wetland in India. Ecosystem Services, 47, 101236.

Sutikno, Vania, \& Anandya, Dudi. (2021). Faktor Yang Mempengaruhi Green Purchase Behavior Generasi Milenial Di Indonesia. Jurnal MEBIS (Manajemen Dan Bisnis), 6(1), 23-30. 